\title{
Watershed of a small river as source of contaminants and biogenic elements
}

\author{
Stepan Klubov*, Iuliia Rozhkova, Victor Tretyakov, and Vasiliy Dmitriev \\ Saint Petersburg State University, 7/9 Universitetskaya emb., 199034, St. Petersburg, Russia
}

\begin{abstract}
There is considered methodology of estimation of contaminants and biogenic elements intake into water objects from urban watersheds by municipal non-point runoff. We used the Volkovka River in St. Petersburg and its watershed for the research because the watershed is characterized by high degree of variety and includes all possible types of urban areas: multi-storey residential constructions, industrial areas, green spaces, cemeteries, wastelands, and even agricultural areas. The research included the monitoring data processing, the watershed analysis by GIStechnologies, and field studies.
\end{abstract}

\section{Introduction}

It is evident that big urban and industrial zones consume enormous volumes of relatively clean fresh water. Therefore, the zones are usually situated near big resources of the fresh water that is rivers and lakes. So the zones contaminate the rivers and lakes, and, in turn, the World Ocean. There are three main sources of the contamination that is waterborne industrial waste, residential sewage, and urban runoff. The industrial waste and the residential sewage are the contaminated water, which previously was taken up from the water resource into the city water supply and treatment system. The urban runoff is atmospheric precipitation, which was contaminated by an urban area. It is divided into urban storm water runoff, and non-point discharge from the urban area. The discharge includes both surface runoff and ground water runoff.

The industrial waste and the residential sewage can be purified. Of course, there is no the utter purification. In the ideal case, we can say about the purification in accordance with the law. The urban storm water runoff also can be purified. However, the runoff is not purified as a rule. Nevertheless, the non-point discharge entirely cannot be purified. Therefore, the estimation of aquatic objects contamination by the non-point discharge is necessary for integral assessment of the objects ecological status and ecological wellbeing. We must take into account the urban storm water runoff and non-point discharge contamination for definition of anthropogenic impact on aquatic ecosystems. St. Petersburg affects the Finnish Gulf ecosystem. For this reason, the problem of the precise estimation of contaminants non-point discharge from the city area has international signification.

\footnotetext{
* Corresponding author: klubov stepan@mail.ru
} 
The problem is widely discussed in scientific literature. Research studies of discharges of untreated contaminated storm water runoff into receiving waters first were performed in the 1970s. The Nationwide Urban Runoff Program (NURP, USA) [1] was carried out between 1978 and 1983 in twenty-eight major cities. It was one of the first national studies identifying sources and pollutants in urban storm water runoff. The program resulted in the amendment of the Clean Water Act and the adoption of the Water Quality Act of 1987 for discharges of industrial and municipal storm water runoff [2]. Australia also issued new Water Quality Policy in 2003. It was periodically updated. The Policy addresses the quality of storm water runoff discharges and other non-point sources, which may have deleterious impacts on the receiving waters [2]. The first studies of quality of storm water runoff in Bucharest, Romania were performed in 2017 [1]. The research ascertained the characteristics of the urban storm water runoff from residential areas in Bucharest and compared the pollutants intakes rates with the international data. Korean research [3] was devoted to urban watershed of Daejeon City and sewer systems. There were also measured the storm water runoff discharge characteristics and was assessed the impact of suspended matter, organics, and nutrients in the first flush on the surface water quality. The vast majority of studies indicated in the urban storm water runoff such common pollutants and parameters as heavy metals (especially copper, lead, and zinc), biological oxygen demand (BOD), total suspended solids (TSS), and significant level of fecal coliform. These components and toxic pollutants impair quality of receiving water resources. For instance, high level of total suspended solids reduces penetration of photosynthetically active solar radiation into water layer. High amounts of nutrients can entail phytoplankton blooms and lead to red tides occurrence. Oxygen-demanding substances cause anoxia and hypoxia, while the pathogens and disease-causing organisms transported with feces water can lead to sicknesses of swimmers and water users. Road salts are also can lead to increase of toxic chlorine concentrations, while oil and gas residues brought from driveways and parking lots can have detrimental impact on environment of receiving water objects [4]. The mentioned consequences of the contaminated urban storm water runoff illustrate the necessity of effective implementation of storm water management to control pollution sources and the volumes of the storm water runoff. These actions can include creation of green infrastructure, green roofs, and grassed swales to decrease erosion and the percentage of impervious surface covers, elaboration of sedimentation control (ESC) measures, land use controls, minimizing directly connected impervious areas, creation buffer and filter strips, infiltration practices (basins and trenches), swirl-type concentrators, storm water drainage wells and other methods [4-7].

\section{Materials and methods}

We used for the estimation the monitoring data of the North-Western Department for Hydrometeorology and Environmental monitoring (St. Petersburg, Russia), the

Committee for Nature Use, Environmental Protection and Ecological Safety of St. Petersburg, and the State Unitary Enterprise (SUE) "Vodokanal of St. Petersburg". The Volkovka River has length more than $15 \mathrm{~km}$, and over 100 wastewater outlets. The outlets were spatially located according to reports of the water withdrawers, which were submitted to the Committee for Nature Use, Environmental Protection and Ecological Safety of St. Petersburg. We used data of the SUE "Vodokanal of St. Petersburg" as invaluable resource of information about the river and the sewage water expenditure and the chemical water compositions. In addition, we measured the river discharge at various places by means of the surface-float method. The estimation of the contaminants and biogenic elements intake into the Volkovka River by means of the surface runoff and sewage was processed according to mass balance methods. We calculated alteration of the substances amounts 
along the river between the upstream and downstream cross sections. There were calculated contributions of the sewage and surface runoff to the alteration. The substances intakes with sewage were estimated on the base of State Unitary Enterprise "Vodokanal of St. Petersburg" data for 2017-2019. The substances intakes with the surface runoff were calculated according to methodology of the SUE "Research and engineering institute for water supply, sewage systems, hydraulic engineering structures and engineering hydrogeology «NII VODGEO» (Moscow, Russia). The methodology includes the calculation methods for estimation of the intakes with snowmelt, rainfall, and road washings runoff. The surface runoff includes these three types of runoff.

The Volkovka River drainage area boundary was designated by means of the ArcGIS tool "Watershed" on the base of the "Aster" digital terrain model, which was created by radar remote sensing (fig. 1). The initial model was previously modified by means of ArcGIS to remove distortions of the ground surface altitudes due to the radar echoing from the roofs. We used for this purpose scheme of the precise ground surface altitudes within St. Petersburg. The processing was carried out with usage of elaborated geoprocessing models.

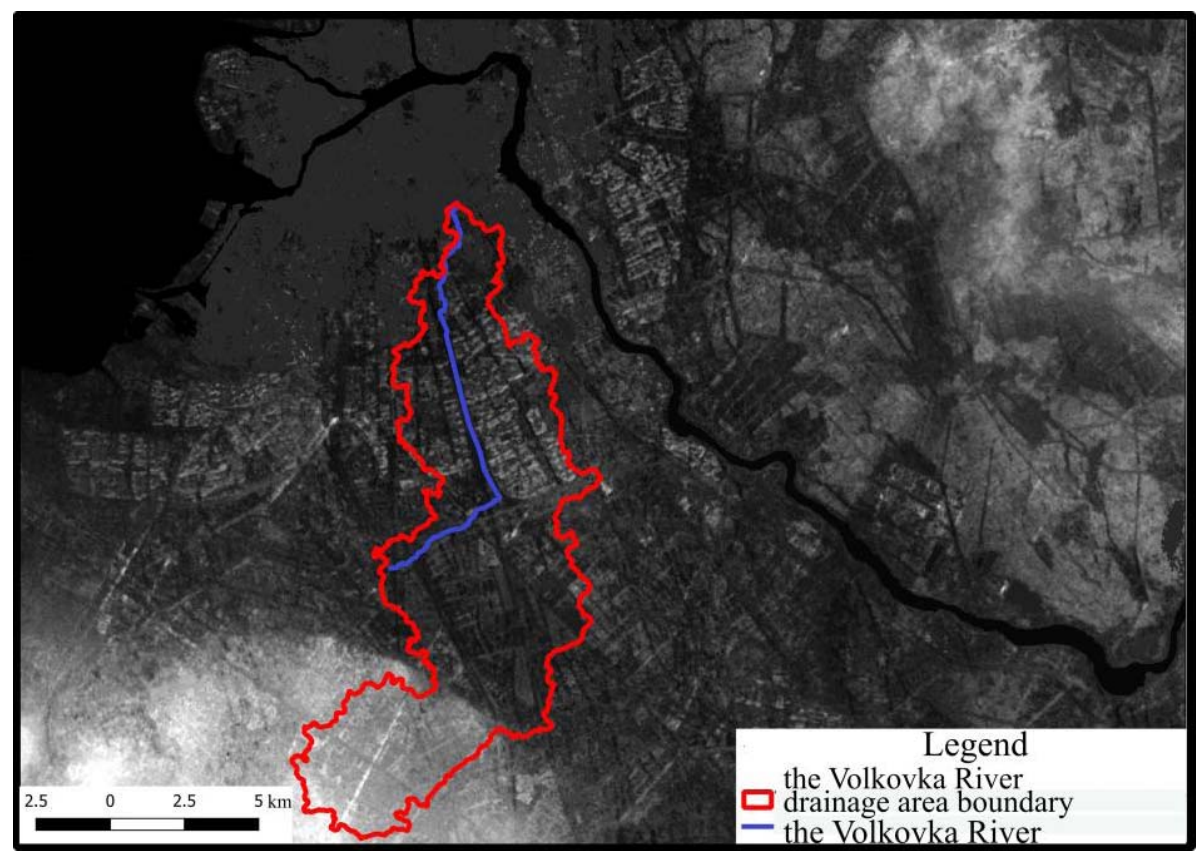

Fig. 1. The result of the Volkovka River drainage area designation

For the watershed segregation in various area types, we carried out supervised classification by means of Quantum GIS. We used multispectral image of Sentiel-2 satellite, which was snapshotted $25^{\text {th }}$ June 2020 . The image sensor resolution is equal to 10 $\mathrm{m}$. Before the supervised classification, we created the vector layer of the surface etalon zones. There was prepared the composite image consisted of red, green, and near infrared range of spectrum for the etalon zones definition. The image ranges combination fits for revealing of the various urban zones. Subsequently we distinguished in the composite raster by means of reclassification operation blocks of cells corresponded to the various types of surface. The type numbers were based into the attribute table of the vector layer of the surface etalon zones. The supervised classification was carried out by means of "Dzetsaka classification dock" module on the base of the composite raster and the vector layer of etalon zones. The classification result is single grey channel image with five classes of 
spatial objects. Then the grey image was modified in single channel false color one for improvement of the visual acceptability. The reclassified raster was vectorized. The polygons of each surface type were exported in separate shapefiles. Total area of each surface type polygons was calculated.

\section{Results and discussion}

The Volkovka River watershed according to our research is equal about $97,3 \mathrm{~km}^{2}$ (fig. 1). There are distinguished 5 types of the surface within the Volkovka River drainage area (fig. 2).

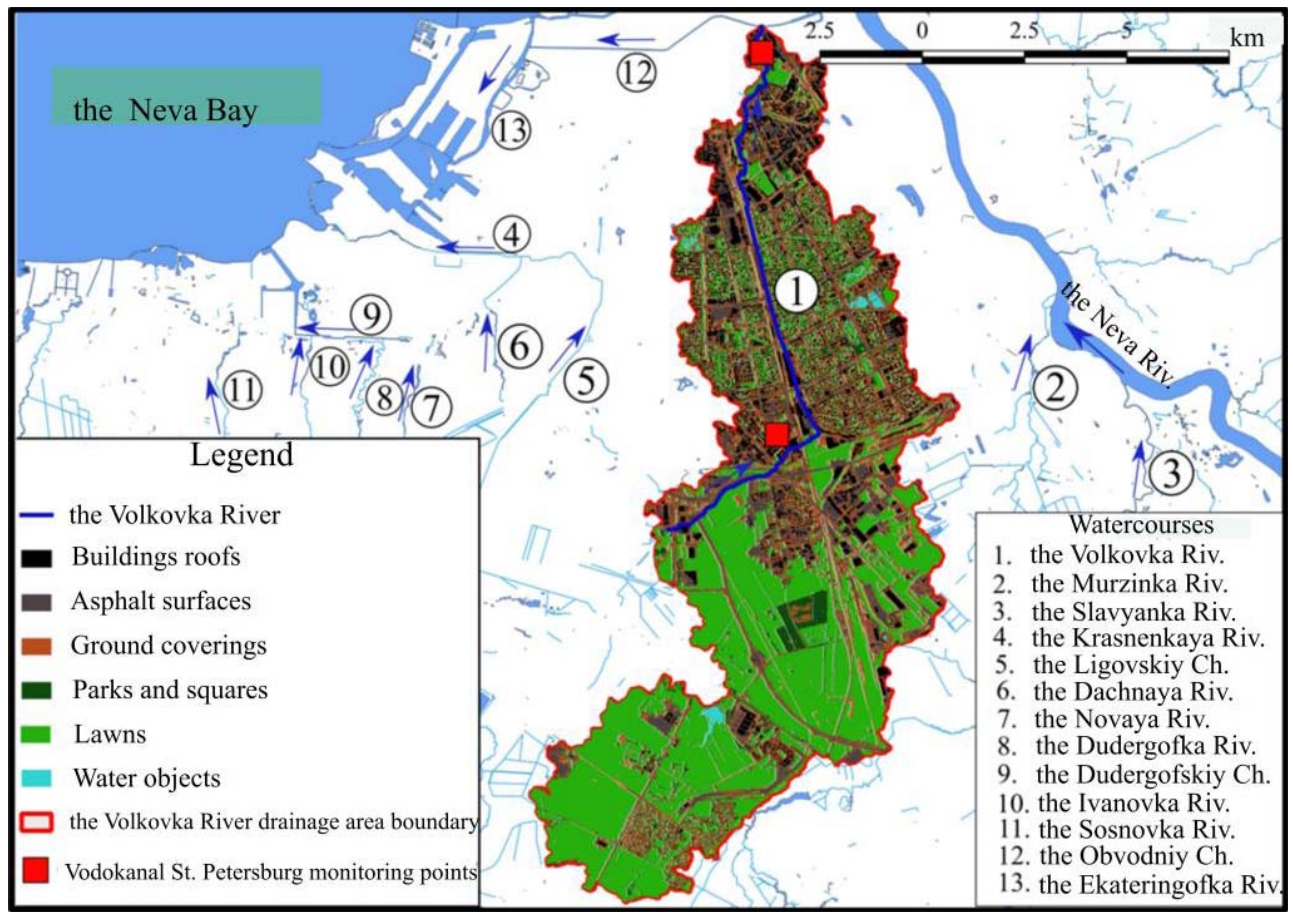

Fig. 2. Types of the surface within the Volkovka River drainage area

The various types of the surface are characterized by different values of the runoff code or the leakage flow rate in ecological terminology. The code demonstrates the part of atmospheric precipitation, which is transformed into surface runoff. Results of the code calculation are presented in table 1 .

Table 1. Types of the surface

\begin{tabular}{|c|c|c|}
\hline Surface type & $\begin{array}{c}\text { Share of the drainage area, } \\
\%\end{array}$ & The runoff code $\left(\psi_{\partial}\right)$ \\
\hline Lawns & 49 & 0.1 \\
\hline Ground without vegetation & 20 & 0.2 \\
\hline Asphaltic surface & 13 & 0.7 \\
\hline Parks, squares, cemeteries & 10 & 0.2 \\
\hline Buildings roofs & 8 & 0.5 \\
\hline Water surface & $<1$ & \\
\hline
\end{tabular}


About a half of the drainage area is occupied by grass vegetation. The larger fraction of the watershed is former agricultural land near Shushary town in the southern part of the watershed. Actually the former agricultural land does not use in agriculture and is covered by grass vegetation. Asphaltic surface and buildings roofs occupy about $20 \%$ of the watershed. Vast residential areas of multistory buildings are situated in the central and northern parts. Parks, gardens, squares, and cemeteries occupy about $10 \%$ of the watershed. The residential areas were built several decades ago. The areas include many leafy escapes. Old-time cemeteries are located within the northern part of the watershed. The cemeteries have been overgrown by tree and shrub vegetation.

Table 2 demonstrates results of calculation of intakes of contaminants and biogenic elements with the surface runoff and sewage into the Volkovka River between the monitoring stations of the State Unitary Enterprise "Vodokanal of St. Petersburg" (fig. 2). Almost all the outlets into the Volkovka River are ones of storm water drainage. The surface runoff from the watershed is the main source of the contaminants and biogenic elements intakes into the river (table 2, columns A and B). Increase of the total nitrogen amount in the river flow between the downstream and upstream cross sections of the monitoring (fig. 2) during 2017-2019 is essentially less than the total nitrogen intake with the surface runoff from the watershed at the river stretch between the cross sections.

Table 2. Intake of contaminants into the Volkovka River with sewage and surface runoff from the partial watershed

\begin{tabular}{|c|c|c|c|c|}
\hline \multicolumn{5}{|c|}{$\begin{array}{l}\text { A - contaminant intake with surface runoff } \\
B \text { - contaminant intake with sewage } \\
\text { AC - ratio of the contaminant intake with the surface runoff to the contaminant } \\
\text { amount alteration between the downstream and upstream monitoring points } \\
\text { BC - ratio of the contaminant intake with the sewage to the contaminant amount } \\
\text { alteration between the downstream and upstream monitoring points }\end{array}$} \\
\hline & \multicolumn{4}{|c|}{2017} \\
\hline Substance & $\begin{array}{l}\text { A, metric } \\
\text { tons }\end{array}$ & $\begin{array}{l}\mathrm{B}, \text { metric } \\
\text { tons }\end{array}$ & $\mathrm{AC}, \%$ & $\mathrm{BC}, \%$ \\
\hline Total nitrogen & 136.71 & 22.33 & 127 & 21 \\
\hline Total phosphorus & 12.34 & 2.21 & 96 & 17 \\
\hline Aluminium & 0.23 & 1.86 & 28 & 6 \\
\hline Suspended solids & 335.74 & 79.87 & 82 & 19 \\
\hline Copper & 0.10 & 0.019 & 161 & 29 \\
\hline Oil products & 6.57 & 1.66 & 64 & 16 \\
\hline $\begin{array}{l}\text { Synthetic surface active } \\
\text { substances }\end{array}$ & 8.80 & 1.30 & 129 & 19 \\
\hline \multirow[t]{3}{*}{ Zinc } & 0.72 & 0.13 & 187 & 33 \\
\hline & \multicolumn{4}{|c|}{2018} \\
\hline & $\begin{array}{l}\text { A. metric } \\
\text { tons }\end{array}$ & $\begin{array}{l}\text { B. metric } \\
\text { tons }\end{array}$ & AC. $\%$ & BC. $\%$ \\
\hline Total nitrogen & 80.57 & 19.59 & 265 & 64 \\
\hline Total phosphorus & 6.46 & 1.50 & 30 & 7 \\
\hline Aluminium & 1.57 & 0.48 & 47 & 14 \\
\hline Suspended solids & 328.11 & 109.28 & $<0$ & $<0$ \\
\hline Copper & 0.08 & 0.03 & 23 & 7 \\
\hline Oil products & 0.29 & 0.51 & 310 & 60 \\
\hline $\begin{array}{l}\text { Synthetic surface active } \\
\text { substances }\end{array}$ & 3.52 & 0.78 & 91 & 20 \\
\hline
\end{tabular}




\begin{tabular}{|l|c|c|c|c|}
\hline Zinc & 0.70 & 0.13 & 259 & 48 \\
\hline & \multicolumn{4}{|c|}{2019} \\
\hline & $\begin{array}{c}\text { A. metric } \\
\text { tons }\end{array}$ & $\begin{array}{c}\text { B. metric } \\
\text { tons }\end{array}$ & AC. \% & BC. \% \\
\hline Total nitrogen & 95.79 & 24.69 & 486 & 125 \\
\hline Total phosphorus & 6.02 & 1.76 & 252 & 73 \\
\hline Aluminium & 5.37 & 0.87 & 270 & 44 \\
\hline Suspended solids & 453.69 & 98.80 & 739 & 161 \\
\hline Copper & 0.12 & 0.024 & 252 & 73 \\
\hline Oil products & 0.36 & 0.10 & $<0$ & $<0$ \\
\hline $\begin{array}{l}\text { Synthetic surface active } \\
\text { substances }\end{array}$ & 4.91 & 0.96 & 187 & 37 \\
\hline Zinc & 0.85 & 0.20 & 54 & 13 \\
\hline
\end{tabular}

Dynamics of the total phosphorus at the river stretch shows the analogous particularity in 2017 and 2019. Probably, a portion of the chemical compounds with nitrogen and phosphorus entered from the water into the benthic sediment. In 2017 and 2019 increase of amounts of copper and suspended substance between the cross sections also was essentially less than intakes of these substances with the surface runoff from the partial watershed between the sections. Probably, there is deposition of the suspended material and heavy metals at the river stretch. Intake of surface-active compounds from the partial watershed into the river in period of 2017-2019 was greater than increase of the compounds between the downstream and upstream sections. Apparently, some portion of the compounds was buried in the bottom deposits.

Nevertheless, the increases of the amounts of phosphorus and copper compounds, and suspended matter between the sections in 2018 was greater than the intakes of the compounds from the partial watershed with the surface runoff and the sewage. It is possible that some amounts of the phosphorus and copper compounds, and particles of the bottom silt penetrated from the bottom sediments into the water flow.

Of course, escapement of the contaminants from the bottom deposits demands additional detailed research. We can merely suppose existence of such processes at the river stretch.

\section{Conclusions}

The Volkovka River watershed and its spatial structure was for the first time ever determined by means of GIS-technologies. There are originally calculated intakes of a number of contaminant in the Volkovka River from the watershed with the non-point surface runoff. The elaborated methodology can be used for analogous researches of urban rivers and watersheds.

Only about $20 \%$ of the surface runoff from the Volkovka River watershed is gathered in the storm-water sewers. The main source of the contaminants intake into the river is the non-point surface runoff from the watershed.

There are processes of the biogenic elements (compounds of nitrogen and phosphorus), heavy metals (copper and zinc), and surface-active compounds accumulation in the bottom deposits. Nevertheless, the opposite processes of the contaminants passage from the bottom deposits into the water layer can periodically take place. The mass exchange processes are of importance in the river chemical characteristics evolvement.

The reported study was funded by RFBR, projects numbers 19-05-00683a and 19-05-00508. 


\section{References}

1. D. Rădulescu, G. Racovițeanu, X. Swamikannu, E3S Web of Conf. 85, 07019 (2019)

2. D. Rădulescu, G. Racovițeanu, A. Pienaru, 3rd International Conference Water 2016, Conference Proceedings, 236-244 (2016)

3. G. Kim, J. Yur, J. Kim, J. of Environ. Manag., 85, 9-16 (2007)

4. Managing storm water runoff to prevent contamination of drinking water. Source Water Protection Practices Bulletin. (United States Environmental Protection Agency, Office of Water, Washington, D.C., 2001)

5. R. K. Craig, Nat.Resources \& Env., 21(4), 36-38 (2007)

6. B. R. Zivkovich, D. C. Mays, PLoS ONE 13(5), e0196782 (2018)

7. C.J. von der Heyden, G. C. Pegram, K. Pema, Water Sc.\& Techn. 55(3), 071 